\title{
Anti-Diabetic, Anti-Inflammatory and Antioxidant Properties of Four Underutilized Ethnomedicinal Plants: An in Vitro Approach
}

Sudeshna Datta

Industrial Section Indian Museum, Botanical Survey of India, Kolkata, India

Tapan Seal ( $\square$ kaktapan65@yahoo.co.in )

Botanical Survey of India

\section{Research}

Keywords: Ethnomedicinal plants, Antioxidant, Effect of solvent, HPLC, In vitro Anti-inflammatory, In vitro Anti-diabetic

Posted Date: October 21st, 2020

DOI: https://doi.org/10.21203/rs.3.rs-93293/v1

License: () (7) This work is licensed under a Creative Commons Attribution 4.0 International License. Read Full License 


\section{Abstract}

Background : In the present study, antidiabetic, anti-inflammatory activities and antioxidant properties in four diverse dissolvable concentrates of four lesser known ethnomedicinal plants viz. Apluda mutica, Mikania micrantha, Kyllinga nemoralis and Cleome rutidosperma were investigated.

Methods: The benzene, chloroform, methanol and 70\% aqueous (aq.) ethanol extract of these plants were tried for antioxidant by various established in vitro systems like total phenolic content, DPPH free radical scavenging, ABTS radical cation scavenging, metal chelating activity. Anti-diabetic and antiinflammatory activities were explored by quantifying a-amylase, a-glucosidase and protein denaturation inhibitory activities of the investigated plants.

Results: Among the various solvents $70 \%$ aq. ethanol extract of $M$. micrantha had the highest total phenolic content ( $230.450 \pm 0.12 \mathrm{mg} \mathrm{GAE} / \mathrm{g}$ extract), DPPH \& ABTS radical scavenging activity, FRAP value (4.122 $\pm 0.004 \mu \mathrm{M}$ Trolox equivalent/ $\mathrm{g}$ dry extract), anti-lipid peroxidation capacity, reducing power and metal chelating activity. The highest amount of total flavonoid was detected in the $70 \%$ aq. ethanol extract of $C$. rutidosprema (71.050 $\pm 0.058 \mathrm{mg} \mathrm{RE} / \mathrm{g}$ extract. Similarly M. micrantha also exhibited significantly lower IC ${ }_{50}$ values for the percentage inhibition of a-amylase $\left(\mathrm{IC}_{50} 58.44 \pm 0.012 \mu \mathrm{g} / \mathrm{ml}\right)$ and a-glucosidase $\left(\mathrm{IC}_{50} 113.31 \pm 0.010 \mu \mathrm{g} / \mathrm{ml}\right)$ compared to acarbose $\left(\mathrm{IC}_{50}=53.8 \pm 0.009 \mu \mathrm{g} / \mathrm{ml} ; \mathrm{IC} 50=79.48 \pm 0.006 \mu \mathrm{g} / \mathrm{ml}\right.$ respectively) $(p \leq 0.05)$. Anti-inflammatory activity was determined by using protein denaturation assay and $M$. micrantha showed significant lower $\mathrm{IC}_{50}$ value for the inhibition of protein denaturation $\left(\mathrm{IC}_{50}=\right.$ $89.27 \pm 0.008 \mu \mathrm{g} / \mathrm{ml}$ ) compared to other plants under investigation. Quantification of polyphenolics by HPLC showed the presence of different phenolic acids in varying amounts.

Conclusion: Therefore, the results indicate that these plants were shown to contain a remarkable amount of different bio-active compounds, thus confirming their involvement in several biological activities and to serve as a potential antioxidative, anti-inflammatory and anti-diabetic agent in food and pharmaceutical industries.

\section{Background}

Reactive oxygen species (ROS) are responsible for various degenerative diseases like Parkinson's arthritis, chronic inflammatory diseases, cancer etc. Synthetic antioxidant molecules used to treat free radical damage of our body has several side effects like carcinogenesis, liver damage etc. Plants materials are rich source of antioxidant molecules like phenolics, flavones, flavonoids, anthocyanin, quinones, coumarins, alkaloids, amines and other metabolites that are reported with different biological activities (Seal and Chaudhuri 2015).Studies have shown that many of these antioxidant compounds possess antiinflammatory, anti-atherosclerotic, antitumor, antiulcer, anti-mutagenic, anti-carcinogenic, antibacterial and antiviral activities (Sala et al. 2002). These secondary metabolites possess manifold functions and hence widely used in the therapy, agriculture, scientific research and countless other areas (Vasu et al. 2009).The significance of plants as a store house of potential drugs has been variously established in the recent years. Drugs from plants being easily available, inexpensive, and seldom with side effects have increased the awareness about the importance of medicinal plants. The plants which have been used medicinally over a period of time therefore constitute the most obvious alternative of study to probe for therapeutically effective new drugs sources.

Medicinal plants have been variously investigated for their antioxidant properties. Natural antioxidants have proved efficacious in preventing the destructive processes caused by oxidative stress (Zengin et al.2011).The routine synthetic antioxidant compounds like Propyl gallate, Butylated hydroxyanisole and Butylated hydroxy toluene have shown to possess lethal effects, and this finding has promoted research into the properties of naturally occurring antioxidants (Fejes et al. 2000). Antioxidants, especially polyphenols which are plant-derived have gained significant applications due to their would-be health benefits.

Knowledge of the chemical constituents of plants is desirable because such information will be value for synthesis of complex chemical substances (Parekh and Chanda 2007). A wide array of medicinal plants has not been studied to verify the claims made by traditional folks about their usefulness in treating diseases.Folklore elucidates the use of plants in treating several diseases like diabetes, arthritis, wound, cancer and tumors (Silja et al. 2008). All these diseases are related to the imbalance of ROS antioxidant molecules in our body. Therefore our study aimed to assess the in vitro antioxidant properties in four different solvent extracts of four lesser known ethno-medicinal plants viz. Apluda mutica,Mikania micrantha,Kyllinga nemoralis and Cleome rutidosperma, grown in India. The study was further extended to evaluate the in vitro anti-diabetic and anti-inflammatory activities of plant resources used in traditional medicine in India.

Apluda mutica L. of the family Poaceae is a very less known ethnomedicinal plant. Paste of whole plant is applied on mouth sores of cattles, plant juice is taken to cure dysentery (Adhikari et al.2010; Shukla et al. 2013).

Mikania micrantha Kunth belonging to family Asteraceae is a known invasive alien species of India. The leaf juice is applied for wound healing and decoction of leaves is taken to treat diabetes and rheumatism (Shil and Dutta Choudhury 2009 ;Chetia et al. 2014).

Kyllinga nemoralis (J.R. Forst. \& G. Forst.)Dandy ex Hutch.\& Dalziel is common wetland sedge of the family Cyperaceae. Traditionally the plant is used treat many diseases. The leaves are used to treat diabetes, fever, hepatopathy, splenopathy and tumours. The rhizomes are anti-diarrhoeal, diuretic, stomachic, and expectorant (Warrier et al. 1995 ; Khory and Katrak 1999).

Cleome rutidosperma DC.of the family Cleomaceae is a low lying herb common in wasteland throughout India. Leaf juice is applied for wound healing. Roots possess anti-inflammatory activity (Chauhan 2001; Chakraborty and Roy 2010).

\section{Methods}


The plant materials viz. Mikania micrantha, Apluda mutica, Kyllinga nemoralis and Cleome rutidosperma were collected from various locations of Kolkata and Howrah, India and identifications were authenticated at Botanical Survey of India, Howrah. The voucher specimens of each plant materials were preserved at the Plant Chemistry department of our office under registry no. BSI/Chem/SD 006, BSI/Chem/SD 007, BSI/Chem/SD 008, and BSI/Chem/SD 009 separately. Plant materials were shade dried, pulverized and stored in an airtight container for further study.

\section{Extraction of plant material}

For preparation of plant extracts, one gram dry sample was extracted separately with $20 \mathrm{ml}$ of methanol, $70 \%$ aq. ethanol, chloroform and benzene with continuous stirring, for 18-24 $\mathrm{h}$ at ambient temperature. The extracts were subsequently filtered with Whatmanno. 1 filter paper and diluted to $25 \mathrm{ml}$ with corresponding extracting solutions. These extracts were analyzed for their antioxidant profiling, anti-diabetic and anti-inflammatory study.

\section{Antioxidant activity}

\section{Estimation of total phenolic content}

Folin-Ciocalteu procedure was followed to estimate total phenolic content of the plant extracts (Datta et al. 2019), and was expressed as mg/g gallic acid equivalent (GAE). To $100 \mu \mathrm{l}$ of different plant extract, $1.0 \mathrm{ml}$ of Folin-Ciocalteu reagent and $0.8 \mathrm{ml}$ of sodium carbonate (7.5\%) were added and incubated for 30 mins after proper mixing. Absorption was measured at $765 \mathrm{~nm}$ (UV-visible spectrophotometer Shimadzu UV1800).

\section{Estimation of total flavonoid content}

Estimation of total flavonoid content was achieved following the standard method (Datta et al. 2019) and was expressed as mg/ g rutin equivalent (RE). To $0.5 \mathrm{ml}$ of extract, $0.5 \mathrm{ml}$ of ethanolic aluminium chloride (2\%) solution was added. Theabsorbance was measured at $420 \mathrm{~nm}$ (UV-visible spectrophotometer Shimadzu UV 1800) after $1 \mathrm{hr}$ incubation.

\section{Ferric Reducing Antioxidant Power (FRAP) Assay}

Ferric Reducing Antioxidant Power (FRAP) was measured and expressed as trolox equivalent (TE) mg/ g dry extract (Datta et al. 2019). The FRAP working solution was prepared by mixing $300 \mathrm{mM}$ sodium acetate buffer ( $\mathrm{pH} 3.6), 10 \mathrm{mM} \mathrm{TPTZ} \mathrm{(2,} \mathrm{4,} \mathrm{6-tripyridyl} \mathrm{triazine)} \mathrm{solution} \mathrm{in} 40 \mathrm{mM}$ HCl and $20 \mathrm{mM}$ ferric chloride solution in a ratio of 10:1:1 (v/v/v). $1 \mathrm{ml}$ of plant extract was then added to $2.85 \mathrm{ml}$ of FRAP working solution and incubated at $37^{\circ} \mathrm{C}$ for 30 min in dark. The increase in absorbance was measured at $593 \mathrm{~nm}$ in a UV-visible spectrophotometer (Shimadzu UV 1800).

\section{Measurement of reducing power}

The reducing power of the extracts wascompletedand calculated as ascorbic acid equivalent (AAE) in mg/ g of dry material (Datta et al. 2019). 100 $\mu$ l of plant extracts were mixed with phosphate buffer $(2.5 \mathrm{ml}, 0.2 \mathrm{M}, \mathrm{pH} 6.6)$ and $2.5 \mathrm{ml}$ potassium ferricyanide (1\%). The mixture was incubated at $50^{\circ} \mathrm{C}$ for $20 \mathrm{~min} .2 .5$ $\mathrm{ml}$ aliquots was taken from mixture and added to the equal volume of $10 \%$ trichloroacetic acid, which was then centrifuged at $3000 \mathrm{rpm}$ for $10 \mathrm{~min}$. The upper layer of the resulting $(2.5 \mathrm{ml})$ was added to the equal amount of distilled water and $0.5 \mathrm{ml}$ freshly prepared ferric chloride solution (0.1\%) and kept in dark for 5 min. The absorbance of resulting solution was estimated at $700 \mathrm{~nm}$ in a UV-visible spectrophotometer (Shimadzu UV 1800).

\section{DPPH (2,2-Diphenyl-1-picryl-hydrazyl) assay}

Free radical scavenging ability of the extracts was determined using the stable radical DPPH (1, 1-diphenyl-2-picrylhydrazyl) following the process of Dutta et al (Datta et al. 2019). $100 \mu \mathrm{l}$ of the tested sample were mixed with $3.9 \mathrm{ml}$ of methanolic DPPH solution (25 mg/L). After $30 \mathrm{mins}$ incubation in dark, the absorbance was measured at $517 \mathrm{~nm}$ in a UV-visible spectrophotometer (Shimadzu UV1800). The capability of test sample to scavenge the DPPH radical was determined.

\section{ABTS [2, 2'-azinobis-(3-ethylbenzothiazoline-6-sulfonic acid)] assay}

The 2, 2'-azino-bis (3-ethylbenzothiazoline-6-sulfonic acid) (ABTS) radical cation (ABTS ${ }^{+}$) scavenging activity was measured according to the method described by Dutta et al (Datta et al. 2019). To aq. solution of ABTS ( $7 \mathrm{mM})$, potassium persulphate solution ( $2.45 \mathrm{Mm}$, final concentration) was added and incubated in dark overnight for free radical generation. To determine the scavenging activity, $1 \mathrm{ml}$ of diluted ABTS ${ }^{+}$solution was added to $10 \mu$ l of plant extract, and the absorbance at $734 \mathrm{~nm}$ in a UV-visible spectrophotometer (Shimadzu UV1800).

\section{Metal chelating property}

For the estimation of metal chelating property of experimental plant extract, the process of Lin et al. was followed with slight modifications (Datta et al. 2019). $1 \mathrm{ml}$ of plant extracts was added to a $200 \mu$ ferrous chloride $(2 \mathrm{mM})$ and $400 \mu$ f ferrozine $(5 \mathrm{mM})$. The mixture was incubated for 10 mins and absorbance was taken at $562 \mathrm{~nm}$.

\section{Anti-lipid peroxidation in linoleic acid system}

Anti-lipid peroxidation was assayed as described by Dutta et al, with modifications (Datta et al. 2019). $1 \mathrm{ml}$ of plant extract was added $130 \mu \mathrm{l}$ of linoleic acid solution followed by addition of $99.8 \%$ ethanol $(10 \mathrm{ml})$ and $10 \mathrm{ml}$ sodium phosphate buffer $(\mathrm{pH} 7,0.2 \mathrm{M})$. The mixture was made upto $25 \mathrm{ml}$ and incubated at $40^{\circ} \mathrm{C}$ upto 360 hours. Extent of oxidation was measured by thiocyanate method. $75 \%$ ethanol $(10 \mathrm{ml}), 30 \%$ aq. Solution of ammonium thiocyanate ( $\left.0.2 \mathrm{ml}\right)$, 
sample solution $(0.2 \mathrm{ml})$ and ferrous chloride $(20 \mathrm{mM}$ in $3.5 \% \mathrm{HCl}, 0.2 \mathrm{ml})$ added sequentially. The absorbance was measured at $500 \mathrm{~nm}$ after $3 \mathrm{mins}$ incubation.

\section{Quantitative profiling of phenolic acids and flavonoids by RP-HPLC}

\section{Preparation of standard solutions}

Stock solution of $1 \mathrm{mg} / \mathrm{ml}$ concentration of different phenolic acids and flavonoids viz. protocatechuic acid, gentisic acid, chlorogenic acid, p-hydroxy benzoic acid, vanillic acid, caffeic acid, syringic acid, p-coumaric acid, ferulic acid, sinapic acid, salicylic acid, gallic acid and ellagic acid, catechin, rutin, myricetin, quercetin, naringin, apigenin and kaempferol were prepared by dissolving $10 \mathrm{mg}$ of the respective phenolic acids in $1 \mathrm{ml} \mathrm{HPLC}-\mathrm{grade}$ methanol and the and the resulting volume was made up to $10 \mathrm{ml}$ with the solvent for the Mobile phase (methanol and $0.5 \%$ aq. acetic acid 1:9). A standard curve was obtained by further dilution at $20,40,60,80$ and $100 \mu \mathrm{g} / \mathrm{ml}$ with the mobile phase solvent system. The standard and working solutions were filtered through $0.45 \mu \mathrm{m}$ PVDF-syringe filter prior injection.

\section{Preparation of sample solution}

$1 \mathrm{~g}$ of each coarsely powdered plant samples were extracted using $5 \mathrm{ml} \mathrm{70 \%} \mathrm{aq.} \mathrm{ethanol} \mathrm{with} \mathrm{constant} \mathrm{stirring} \mathrm{for} 24 \mathrm{~h}$. The process was repeated for three times and the final volume was made upto $10 \mathrm{ml}$. The extracts were filtered through $0.45 \mu \mathrm{m}$ PVDF-syringe filter prior injection.

\section{Chromatograph analysis}

Quantification of phenolic acids and flavonoids were performed following the method of Dutta et al (Datta et al. 2019). Separation was achieved by a reversed phase Acclaim C18 column ( 5 micron particle size, $250 \times 4.6 \mathrm{~mm}$ ). The mobile phase contains methanol (Solvent A) and 0.5\% aq. acetic acid solution (Solvent B) and the column was thermostatically controlled at $28^{\circ} \mathrm{C}$ and the injection volume was kept at $20 \mu \mathrm{l}$. The gradient elusion was $90 \%$ solvent $\mathrm{B}$ and $10 \%$ solvent $A$ and flow rate was settled from $1 \mathrm{ml} / \mathrm{min}$ to $0.7 \mathrm{ml} / \mathrm{min}$ in $27 \mathrm{~min}$, from 10 to $40 \%$ solvent $A$ with flow rate $0.7 \mathrm{ml} / \mathrm{min}$ for $23 \mathrm{~min}, 40 \%$ solvent $A$ and $60 \% \mathrm{~B}$ with flow rate $0.7 \mathrm{ml} / \mathrm{min}$ primarily for $2 \mathrm{~min}$ and then flow rate altered from 0.7 to $0.3 \mathrm{ml} / \mathrm{min}$ in $65 \mathrm{~min}$, from 40 to $44 \%$ solvent $\mathrm{A}$ with flow rate 0.3 to $0.7 \mathrm{ml} / \mathrm{min}$ in $70 \mathrm{~min}, 44 \%$ solvent A with flow rate 0.7 to $1 \mathrm{ml} / \mathrm{min}$ for $10 \mathrm{~min}$ duration, solvent A changed from $44 \%$ to $58 \%$ with flow rate $1 \mathrm{ml} / \mathrm{min}$ for $5 \mathrm{~min}$, 58 to $70 \%$ solvent $A$ in $98 \mathrm{~min}$ at constant flow rate $1 \mathrm{ml} / \mathrm{min}$. The mobile phase composition was taken to the original condition (solvent A: solvent B: 10: 90 ) in $101 \mathrm{~min}$ and allowed to run for another $4 \mathrm{~min}$, before the injection of another sample. Total analysis time per sample was $105 \mathrm{~min}$. The presence of phenolics were detected in HPLC chromatograms using a photo diode array UV detector at three different wavelengths (272, 280 and $310 \mathrm{~nm})$ according to absorption maxima of investigated compounds. Each compound was identified by its retention time and by spiking with standards under the same conditions. The quantification of phenolic acids and flavonoids in the plant extracts were analysed by the measurement of the integrated peak area and the amounts were estimated using the calibration curve of the respective standard compound.

\section{Estimation of anti-diabetic property}

\section{Extraction of plant material}

$1 \mathrm{~g}$ of powdered plant sample was extracted with $5 \mathrm{ml} 70 \%$ ethanol on constant stirring for $24 \mathrm{~h}$ at the ambient temperature. The resulting extracts were filtered using Whatman No.1 filter paper and the filtrate was concentrated under vacuum at room temperature. Dried extracts were weighed and further dissolved in double distilled water to yield a stock solution concentration ranging from $5 \mu \mathrm{g} / \mathrm{ml}$ to $50 \mu \mathrm{g} / \mathrm{ml}$.

\section{a-Amylase inhibition property}

This assay was carried out using a modified procedure of McCue and Shetty (McCue, K. Shetty 2004). Different concentration (5-50 $\mu$ g/ ml) of plant extract was mixed with $250 \mu \mathrm{l}$ of sodium phosphate buffer $(0.02 \mathrm{M}, \mathrm{pH} 6.9)$ containing a-amylase solution $(0.5 \mathrm{mg} / \mathrm{ml})$. This solution was incubated at $25^{\circ} \mathrm{C}$ for 10 min, followed by addition of $250 \mu \mathrm{l}$ of starch solution (1\%) in $0.02 \mathrm{M}$ sodium phosphate buffer $(\mathrm{pH} 6.9)$ then further incubated at $25^{\circ} \mathrm{C}$ for $10 \mathrm{~min}$. The reaction was completed by addition $500 \mu \mathrm{l}$ of dinitrosalicylic acid (DNS) reagent. The reaction mixture was incubated for $5 \mathrm{~min}$ in boiling water. The absorbance was measured at $540 \mathrm{~nm}$ using spectrophotometer after cooling to room temperature and further dilution with $5 \mathrm{ml}$ distilled water. Acarbose (Acarbose, $25 \mathrm{mg}$ from Orchid Chemicals \& Pharmaceuticals Ltd.) was used as standard. The a-amylase inhibitory activity was calculated as percentage inhibition (\%).

\section{a- Glucosidase inhibition property}

The inhibition of a-glucosidase assay of the extracts was completed according to the method described by Kim et al.(Kim et al. 2005), using a-glucosidase from Saccharomyces cerevisiae. p-nitrophenylglucopyranoside (pNPG) solution prepared in phosphate buffer (20mM , pH 6.9) was used as substrate. $100 \mu \mu l$ of a-glucosidase $(1.0 \mathrm{U} / \mathrm{cc})$ was pre-incubated with in different concentration $(5-50 \mu \mathrm{g} / \mathrm{ml})$ of the extracts for $10 \mathrm{~min}$, followed by addition of $50 \mu \mathrm{l}$ of pNPG $(3 \mathrm{mM})$ to initiate reaction. The reaction mixture was incubated at $37^{\circ} \mathrm{C}$ for $20 \mathrm{~min}$ and terminated by adding $2 \mathrm{ml}$ of sodium carbonate $(0.1 \mathrm{M})$. The absorbance was measured at $405 \mathrm{~nm}$ using spectrophotometer. Acarbose was used as standard anda-glucosidase inhibitory activity was calculated as percentage inhibition (\%).

\section{Anti-inflammatory activity}

The plant extract was prepared following the same procedure that used for anti-diabetic activity. The anti-inflammatory activity was studied in terms of inhibition of albumin denaturation which was studied according to Vallabh et. al.(Vallabh et. al. 2009) with minor modifications. The reaction mixture (0.5 ml) consisted of $0.45 \mathrm{ml}$ of bovine serumalbumin ( $5 \%$ aqueous solution) and $0.05 \mathrm{ml}$ of plant extracts ( 50 and $200 \mu \mathrm{g} / \mathrm{cc}$ of final volume) which was incubated in 
boiling water bath for 10 mins.After cooling the turbidity was measured at $660 \mathrm{~nm}$. Diclofenac (Dicloran 50 mg, JB Chemicals \& Pharma Ltd.) was used as standard and protein denaturation activity was calculated as percentage inhibition (\%).

\section{Statistical analysis}

All the experiments were done using triplicate samples. Results were represented as value \pm standard error mean (SEM). Experimental results were subjected to univariate analysis of variance (ANOVA), followed by Tukey test $(p \leq 0.05)$ using the statistical package for the social sciences SPSS version17.0 (SPSS Inc., Chicago,Illinois, USA).

\section{Results}

\section{Antioxidant activity}

\section{Effect of solvent system on extractive yield}

The extractive yield of the different solvent extracts of the experimental plants varied according to polarity (Table 1). Maximum extractive yield was observed in methanol extract of $M$. micrantha $(7.21 \pm 0.19 \%)$ and $C$. rutidosperma $(7.17 \pm 0.16 \%)$ and the lowest in benzene extract of $C$. rutidosperma ( $0.538 \pm 0.116 \%)$. The plants showed a higher extraction yield with $70 \%$ aq.ethanol and methanol compared to their chloroform or benzene extracts.

\section{Total phenolic and flavonoid content}

Total phenolic and flavonoid content is expressed as $\mathrm{mg}$ gallic acid equivalent (GAE)/g dry extract mg rutin equivalent (RE)/ $\mathrm{g}$ dry extract respectively and is represented in Table 1. All the extracts showed presence of high amount of phenolics and flavonoids in the $70 \%$ aq. ethanol followed by methanol extracts and it decreased with decreasing polarity. Maximum phenolic content was observed in M. micrantha (230.45 $\pm 0.12 \mathrm{mg} \mathrm{GAE} / \mathrm{g}$ dry extract) and the lowest in $A$. mutica (141.94 $\pm 0.67 \mathrm{mg} \mathrm{GAE} / \mathrm{g}$ dry extract). The total flavonoid content is expressed as equivalent mg rutin equivalent (RE)/g dry extract and was observed to be comparatively lower than the phenolic content. $70 \%$ aq. ethanol extract of $C$. rutidosperma. $(71.05 \pm 0.06 \mathrm{RE} / \mathrm{g}$ dry extract) showed the highest amount of flavonoid content. The flavonoid content in the different solvent extracts under study also decreased with decreasing polarity of the extracting solvent.

\section{Radical scavenging property using DPPH and ABTS radical}

All solvent extractsof the plants studied were subjected to radical scavenging activity assays using both DPPH and ABTS radicals and is expressed as percentage of inhibition of radicals by the extract and is depicted in Table 2. Activities varied widely, from very high to moderate. All samples demonstrated ability to scavenge DPPH and ABTS radicals, however, the plants showed more prominent activity against ABTS radical. Aq. ethanol solution of $M$. micrantha $(87.01 \pm 0.22 \%)$ and $C$. rutidosperma (83.85 $\pm 0.08 \%$ ) exhibited maximum radical scavenging activity using DPPH radicals. Similar observations were made using ABTS radical with $M$. micrantha $(93.30 \pm 0.84 \%)$ and $C$. rutidosperma $(92.67 \pm 0.13 \%)$ having the most promising activity. The scavenging activity was observed to be minimal in the benzene extract for all the plants.

\section{Ferric ion reducing antioxidant power (FRAP)}

All the four different extracts of each plant were subjected to FRAP assay which is expressed as $\mu$ mole Trolox equivalent (TE)/g dry extract and is represented in Table 2. The aq. ethanol and methanol extract showed higher FRAP activity over the chloroform and benzene extract for all the plants. Maximum activity was observed in $70 \%$ aq. ethanol extract of $M$. micrantha $(4.12 \pm 0.004 \mu \mathrm{M} \mathrm{TE})$ and $C$. rutidosperma $(3.73 \pm 0.003 \mu \mathrm{M}$ TE). The FRAP activity of the methanol extract of these plants was also promising.

\section{Reducing property and metal chelating activity}

All the previous experiments indicated that the alcoholic extract of the plants to possess better antioxidant capabilities and subsequently those had been selected for in additional studies. Reducing property is expressed as mg ascorbic acid equivalent (AAE)/g dry extract and is represented in Table 3 . Following a similar trend, $70 \%$ aq. ethanol extract of $M$. micrantha ( $66.52 \pm 0.07 \mathrm{mg} \mathrm{AAE}$ ) followed by $C$. rutidosperma ( $51.90 \pm 0.11 \mathrm{mg} \mathrm{AAE})$ showed the maximum reducing ability. The reducing activity decreased with the decreasing polarity of the solvent. The $70 \%$ aq. ethanol extracts of $M$. micrantha (71.91 $\pm 0.29 \%)$ showed the highest chelating activity expressed as percentage of inhibition of metal ions/g dry extract and represented in Table 3 . Maximum chelating activity is observed in $70 \%$ aq. ethanol extract followed by methanol extract for all the plants under study. The chelating activity of $M$. micrantha and $C$. rutidosperma in methanol extract were also noteworthy.

\section{Anti-lipid peroxidation assay}

Anti-lipid peroxidation assay is represented as percentage of inhibition of lipid peroxidation/g dry extract and is represented in Table 3. M. micrantha (63.16 \pm $0.011 \%$ ) showed maximum inhibition activity in $70 \%$ aq. ethanol extract. The ethanol extract showed greater efficacy in lipid peroxidation activity over other extracts for all the plants.

\section{Quantitative profiling of phenolic acids and flavonoids by RP-HPLC}

A total of 13 phenolic acids (gallic acid, protocatechuic acid, gentisic acid, chlorogenic acid, phydroxy benzoic acid, vanillic acid, caffeic acid, syringic acid, pcoumaric acid, ferulic acid, sinapic acid, salicylic acid and ellagic acid) and 8 flavonoids (catechin, rutin, myricetin, quercetin, naringin, naringenin, apigenin and kaempferol) were analyzed, expressed as $\mathrm{mg} / 100 \mathrm{~g}$ dry plant material (DPM) and is represented in Table 4 . All investigated compounds were successfully separated and responded at $260 \mathrm{~nm}$. The respective phenolic acids and flavonoids were also identified by the recorded absorption spectra, which were 
comparable to the standard substances. Out of 13 phenolic acids under study, A. mutica contained 9 and $M$. micrantha contained 10 phenolic acids. A. mutica contained maximum amount of caffeic acid $(0.63 \pm 0.001 \mathrm{mg} / 100 \mathrm{~g}$ DPM), p-couramic acid $(1.29 \pm 0.002 \mathrm{mg} / 100 \mathrm{~g}$ DPM), ferulic acid $(1.38 \pm 0.001 \mathrm{mg} / 100 \mathrm{~g}$ DPM) and sinapic acid $(1.81 \pm 0.001 \mathrm{mg} / 100 \mathrm{~g}$ DPM). M. micrantha contained highest amount of protocatechuic acid $(0.40 \pm 0.002 \mathrm{mg} / 100 \mathrm{~g}$ DPM $)$ and salicylic acid $(1.56 \pm 0.004 \mathrm{mg} / 100 \mathrm{~g}$ DPM).

\section{Antidiabetic potential by a -amylase and a-glucosidase inhibition assay}

Results were calculated as percentage inhibition (under experimental conditions). The inhibitory activity for the studied plants was also shown to be concentration dependent. The $\mathrm{IC}_{50}$ of each plant extract was determined as the inhibitor concentration (estimated on basis of the dried extract) required inhibiting $50 \%$ of a-amylase activity and a-glucosidase under the described experimental conditions, represented in Table 5 . Acarbose appeared to be most active as a-amylase inhibitor $\left(\mathrm{IC}_{50}=53.8 \pm 0.009 \mu \mathrm{g} / \mathrm{cc}\right)$ followed by that of $\mathrm{M}$. mictantha $\left(\mathrm{IC}_{50}=58.44 \pm 0.012 \mu \mathrm{g} / \mathrm{cc}\right)$ and $A$. mutica $\left(\mathrm{IC}_{50}=63.01 \pm 0.004\right.$ $\mu \mathrm{g} / \mathrm{cc})$. A similar trend is observed for a-glucosidase inhibition where acarbose (IC $\mathrm{S}_{50}=79.48 \pm 0.006 \mu \mathrm{g} / \mathrm{cc}$ ) appeared to be most effective followed by $M$. mictantha $\left(\mathrm{IC}_{50}=113.31 \pm 0.010 \mu \mathrm{g} / \mathrm{cc}\right)$ and $A$. mutica $\left(\mathrm{IC}_{50}=168.84 \pm 0.014 \mu \mathrm{g} / \mathrm{cc}\right)$.

\section{Anti-inflammatory activity by protein denaturation inhibition assay}

Results were calculated as percentage inhibition (under experimental conditions). The inhibitory activity for the studied plants was also shown to be concentration dependent. The $\mathrm{IC}_{50}$ of each plant extract was determined as the inhibitor concentration (estimated on basis of the dried extract) required inhibiting $50 \%$ of protein denaturation under the described experimental conditions and represented in Table 5. Diclofenac appeared to be most active inhibitor of protein denaturation $\left(\mathrm{IC}_{50}=31.32 \pm 0.004 \mu \mathrm{g} / \mathrm{cc}\right)$ followed by that of $\mathrm{M}$. mictantha $\left(\mathrm{IC}_{50}=89.27 \pm 0.008 \mu \mathrm{g} / \mathrm{cc}\right)$ and $\mathrm{C}$. rutidosperma $\left(\mathrm{IC} \mathrm{C}_{50}=98.78 \pm 0.007\right.$ $\mu \mathrm{g} / \mathrm{cc})$.

\section{Discussion}

\section{Antioxidant activity}

\section{Effect of solvent system on extractive yield}

The process of extraction solubilises the phenolic compounds in the plant sample and hence it is an essential part of estimation of antioxidant activity. The effect of solvent system on extraction has been variously studied in wild edibles (Seal 2014). The extraction yield from a plant is largely affected by the plant parts used, extraction procedure, solvent polarity and the chemical properties of the sample (Lopez et al. 2011). In this study four different solvent systems of varying polarity viz. 70\% hydro-ethanol, methanol, chloroform and benzene were used as extracting solvent. The highest extraction yield was found with hydroalcoholic solvent indicating a polar nature of the antioxidant compounds. Addition of water to organic solvent increases polarity and facilitates the extraction of antioxidant compounds of wide range of polarity (Uma et al. 2010). Hydro-alcohol has revealed to be more efficient in extracting phenolic constituents than compared to pure solvent system (Spingo et al. 2007). Comparative better yield from chloroform extract of $A$. mutica suggests presence of antioxidantcompounds of moderate polarity or extraction of pigments.

\section{Total phenolic and flavonoid content}

Phenolics are secondary metabolites assumed an imperative part for their antioxdant activities by chelating metal particles, inactivating lipid free radical chains and forestalling hydroperoxide transformations into reactive oxyradicals (Florence et al. 2011). Inhibitory effects of polyphenolic compounds on mutagenesis and carcinogenesis has also been established (Gursoy et al. 2009). Results of the present study showed that among all the solvent extracts; the hydro-ethanol extracts had the highest phenolic content followed by methanol and it decreased with decreasing polarity. Similar results have been reported in studying the phenolic contentof selected tropical fruits from Malaysia (Alothman et al. 2009). Mukhopadhyay et al. have examined aqueous ethanol effect by employing ethanol: water mixture (50:50, v/v) and obtained a hightotal phenolic content value compared with pure ethanol (Mukhopadhyay et al. 2006). Phenolics are often extracted in higher amounts in more polar solvents such as aqueous methanol/ethanol as compared with absolute methanol/ethanol (Seal et al. 2013) which are in accordance to the finding reported here. Often phenolicsremain associated with different biomolecules like carbohydrate, pigments, terpenes, therefore $100 \%$ recovery of a compound cannot be achieved using a single solvent system. High yieldusing methanol may be due to the ability of the solvent to dissolve the associated biomolecules. Moreover, methanol inhibits phenol oxidase and hence is suitable for extractionof polyphenols. This may be the reason that methanol extract of the selected plants in this studyshowed high phenolic content. In general, 40-80\% ethanol or methanol, had greater efficacy in the extraction of polyphenolic compounds compared to water or pure ethanol or methanol (Jayaprakasha et al. 2008).

Flavonoids have been demonstrated to show a wide scope of pharmacological and biochemical exercises including radical scavenging properties (Pourmorad et al. 2006). The flavonoid content in the plants under study was highest in $70 \%$ ethanol. Similar observation was made in case of Torilis leptophylla where the highest amount offlavonoid content was analyzed in ethanolic extract, followed by that in methanol and benzene (Saeed et al. 2012).

\section{Radical scavenging property using DPPH and ABTS radical}

The antioxidant capacity wasassessed using DPPH and ABTS assays of various extracts.Maximum radical scavenging activitywas observed with $70 \%$ aq. ethanol and the activity decreased with decreasing polarity. The outcome is as per the examination by Sultana et al. on medicinal plants where aqueous ethanol displayed most extreme DPPH radical scavenging activity over absolute ethanol (Sultana et al. 2009). The data suggests that polar components like phenol and flavonoids of the plant studied contributed to the radical scavenging activity. The methanolic extract of these plants are also rich in their flavonoid content and exhibited good scavenging activity. Hagerman et al. have reported free radicals scavenging property increases with the increase in molecular weight of the phenolic compounds and it depends on the number of aromatic rings and nature of hydroxyl group substitution (Hagerman et al. 1998). 
In the FRAP assay, the presence of antioxidants in the sample results in the reduction of Fe+3 to Fe+2 and it reflect the antioxidant potential of the sample. The results indicate that FRAP for both hydro ethanol and methanol extract of all the plants under study were comparable. Highest FRAP is observed in the hydro alcoholic extracts of all the plants which can be attributed to its high content of phenolics in those extracts. A similar observation was made while evaluating the antioxidant activity of Brugeiera gymnorrhiza and Aegialitis rotundifolia (Reddy and Grace 2016).

\section{Reducing property and metal chelating activity}

Metal ions mediate lipid peroxidation to initiate a chain reaction leading to the deterioration of food (Gordon 1990). The catalysis of metal ions also correlates with etiology of cancer and arthritis (Halliwell et al. 1990). Chelating capacity of the investigated plant extracts decreased with the decreasing polarity. A similar trend is followed as recorded forreducing property. In addition, lipid peroxidation and oxidative damage of protein systems ferrous ions also catalyze the conversion of hydrogen peroxide to hydroxyl radical via Fenton reaction. Ferrous ions are the most effective pro-oxidants adequately found in food systems (Yamaguchi et al. 1998). Polyphenols with dihydroxygroups can conjugate metals, preventing metal catalyzed free radical formation (Gua et al. 1996). The metal reducing or chelating ability can be attributed to the high phenol and flavonoid content in the $70 \%$ aq. ethanol extracts.

\section{Anti-lipid peroxidation assay}

Peroxidation of cell membrane lipid is associated with various pathological events such as atherosclerosis, inflammation and liver injury (Singh et al. 2012). The phenolic compounds and other chemical components may suppress lipid peroxidation through different chemical mechanisms, including free radical quenching, electron transfer, radical addition or radical recombination (Mathew and Abraham 2006). Lipid peroxidation is also associated with of rancidity of lipid foods (Gutensperger et al. 1998). The plant extracts under study have highest phenolic content in the $70 \%$ ethanol extract so their anti-lipid peroxidation activity was also higher in their $70 \%$ ethanol extract. This is in accordance with several other investigations on fruits and vegetables where a significant relationship between total phenolic content and peroxidation activity is evident (Velioglu et al. 1998) and in medicinal plants like Hypericum perforatum (Zou et al. 2004).

\section{Quantitative profiling of phenolic acids and flavonoids by RP-HPLC}

Protocatechuic acid is widely distributed naturally occurring phenolic acid. It is also a very common compound present in human diet, present in bran and grain brown rice and also found in many fruits. This phenolic acid showed various pharmacological activities such as anti-inflammatory properties and interaction with several enzymes (Kakkar and Bais 2014). Chlorogenic acid is found in coffee and coffee beans and also found in higher plants. It has been reported to reduce blood sugar levels and potentially exert an anti-diabetic effect (Uma et al. 2010). Even though, presence of appreciable amount of chlorogenic acid in A. mutica there has been no report of its use as an anti-diabetic agent, therefore its potential can further be explored. p-Hydroxybenzoic acid, isolated from plants like Vitex negundo, Paratecoma peroba, Daucus carota, Roystonea regia and Mespilus germanica, possesses antimutagenic, antisickling, estrogenic, and anti-microbial activities (Khadem and Marles 2010). The p-Hydroxybenzoic acid content is K. nemoralis justifies the use of this plant on cuts and wound because of its antimicrobial properties. Vanillic acid is used as a flavouring agent. Hepatoprotective activity of vanillic acid in liver inflammation by concanavalin A-induced liver injury has been proved (Kim et al. 2010). The vanillic acid content of $K$. nemoralis is higher to medicinal sedge Cyperus compressus (Datta et al. 2018a). Caffeic acid is a well-known antioxidant, controls lipid levels inblood and anti-mutagenic (Seal et al. 2017) and only found in A. mutica. Anti-cancer, anti-proliferative, and hepato-protective actions of syringic acid are well known. The maximum amount of syringic acid has been detected in A.mutica compared to the other plants under investigation. Alternanthera paronychioides, a lesser known ethnomedicinal plant used to treat diarrhoea, contains high amount of syringic acid [Datta et al 2018b].p-coumaric acid exhibit strong antioxidant activity and reduce the formation of carcinogenic nitrosamines in the stomach (Ramadoss et al. 2015). High amount of p-coumaric acid has been quantified from $M$. micrantha, and $C$. rutidosperma which also indicates their protective value. Ferulic acid is known for its anti-microbial, anti-inflammatory, anti-cancer activities etc (Mussatto et al. 2007) and it is found in all the plants under study. Sinapic acid showed antioxidant, anti-microbial, anti-inflammatory, anticancer, and anti-anxiety activity (Seal et al. 2016). High amount of sinapic acid in A. mutica and M.micrantha justifies its application on cuts and wounds because of its antimicrobial property. Ellagic acid possesses antioxidant and anti-proliferative activity (Seeram et al. 2005) and acts as a chemo-preventive agent too (Vattem and Shetty 2005). C. rutidosperma contain good amount of ellagic acid which justifies its folklore use as an anti-inflammatory medicine.

Rutin is a flavonol with biological effects, such as antidiabetic effect (Srinivasan et al. 2005) and anticancer activity (Lin et al. 2012) and can potentially be used as a therapeutic agent. Appreciable amountof rutin in M. micrantha suggests their potential use as therapeutic agents. Myricetin has been proven to posses' anticancer, antidiabetic and anti-inflammatory activity (Ong and Khoo 1997). A. mutica contain high amount of myricetin andcan be exploited for its antidiabetic potential. Quercetin is reported to be anti-cancer, anti-histamine, and anti-inflammatory activities (Seal T 2016) which correlates to the antioxidant potential. Apigenin, reduce the risk of cardiac ailments, neurologicalsyndromes, mutagenesis (Mohammad and Elham 2013) and is detected in appreciable amount in C. rutidosperma. Kaempferol might be helpful to prevent the oxidation of low-density lipid proteins, indicating a potential protective role in atherosclerosis. Consumption of kaemferol enriched food with reduces the chances of gastric cancer (Calderon-Montano et al. 2011). Good amount ofkaempferol is detected in M. micrantha and C. rutidosperma and suggests that these plants would render new insight in anti-inflammatory agents. Naringin has been proven to haveanti-inflammatory and anti-cancerous activity (Chen et al. 2016). Inclusion of naringin supplementations to the diet has been proved to be beneficial for the treatment of obesity,diabetes, hypertension, and metabolic syndrome (Alam et al. 2014). M. micrantha has high amount of naringin and therefore can be considered for treatment of the above diseases. Naringenin has anticancerous activity (Kanno et al. 2005) and is being researched as a potential treatment for Alzheimer's disease (Yang et al. 2017). The presence of naringenin is detected only in $C$. rutidosperma and therefore the use of these plants for treatment of Alzheimer's disease needs further attention. 
Diabetes is characterized by high concentrations of blood sugar levels, which can cause serious complications, such as organ failures and/or destruction of the kidneys, eyes, and variouscardiovascular diseases. One of the therapeutic methods is to reduce the hyperglycemia by hindering the absorption of glucose, which is achieved by inhibition of carbohydrate-hydrolyzing enzymes, such as a-amylase and a-glucosidase (Bhandari et al. 2008). Synthetic drugs like miglitol, acarbose and voglibose are used in conjunction with other antidiabetic drugs, but these inhibitors exert gastrointestinal side effectslike abdominal discomfort, flatulence and diarrhea on prolonged use (Shai et al. 2010). As a result of this, there isgrowing interest in discovering new and effective a-amylase and a-glucosidase inhibitors from plants with minimal or no side effects. The inhibition \% for a-amylase are close to that of acarbose, and theinhibition rate for a-glucosidase was lower than that of acarbose for $A$. mutica, K. nemoralis and $C$. rutidosperma but comparable to $M$. micrantha. This indicated that $A$. mutica, $K$. nemoralis and $C$. rutidosperma are a potent inhibitor for a-amylase with mild inhibitory activity against a-glucosidase, whereas $M$. micrantha is a potent inhibitor for both the enzymes. There has been no previous report on the anti-diabetic effect of $A$.mutica and it is evident from the results that it can be considered as a promising source of anti diabetic compound. Anti-diabetic effect of the ethanol extract of the leaves of $M$. micrantha has been studied in alloxan induced diabetic rats (Nurdiana et al. 2013) but the present study elucidates the hypoglycaemic action through enzyme inhibitory action. Similarly for K. nemoralis, the hypoglycaemic activity has been established (Quanico et al. 2008) but not the a-amylase and a-glucosidase inhibition potential, which is elucidated here. The anti-diabetic effectof $C$. rutidosperma has been variously studied in animal model (Okoro et al. 2014) and its effect on glucokinase and glucose phosphatase has been presumed. In this study theexact inhibition of the above stated enzyme has been studied, which is important for thedevelopment of anti-diabetic drug from the plant sources.

Polyphenolic compounds in plants have been shown to inhibit the activities of digestive enzymes due to their ability to bind with proteins. Results from previous studies suggest that phenolic compounds isolated from medicinal plants (Nickavar et al. 2008) have potential to treat Type II diabetes mellitus. Polyphenols are widely distributed throughout the plant kingdom and thus form an integral part of the human diet.Therefore, the inhibition of a -amylase and a-glucosidase found in this study could be due to thepresence of polyphenolic compounds and may potentially provide a natural source of inhibitors.From the calculation of IC50 it is evident that the inhibition is not only dependant of quantity but also on the quality of the polyphenols present. The structural relationship and the a-glucosidase inhibitory activity of six classes of flavonoids have been established (Tadera et al. 2006). Chlorogenic acid, rutin, myricetin and naringin has been proved to have antidiabetic potential.Presence of myricetin, quercetin and chlorogenic acid with their different derivated were responsible for the anti-diabetic activity of Polygonum hyrcanicum (Moradi-Afrapoli et al. 2012). The antidiabetic effect in M. micranthaor $C$. rutidosperma can also be attributed to the combined effect of the polyphenols in the extract. M. micrantha contains high amount of naringin, rutin and appreciable amount of chlorogenic acid which might be responsible for its antidiabetic potential. Similarly the antidiabetic action of $A$. mutica can be attributed to the presence of high amount of myricetin, chlorogenic acidandappreciable amount ofrutin. Myricetin and rutin is also identified in $C$. rutidosperma. Only myricetin has been identified from $K$. nemoralis, which justifies its comparatively low antidiabetic potential compared to M. micrantha and $A$. mutica.

\section{Anti-inflammatory activity by protein denaturation inhibition assay}

Denatured proteins are heterogeneous conformational isomers and lack in their proposed natural activities. However, the significance of denatured protein is expanding as it has demonstratedto be the underlying cause of many neurodegenerative and inflammatory diseases (Chang 2009). Anti-protein denaturation activity of these plant extract could be used as a potent mitigating drug in future. The anti-protein denaturation study was performed using bovine serum albumin (BSA). Antigens associated with type-III hypersensitivity reaction is expressed when protein is denatured, which is also related to diseases such as glomerulo-nephritis, serum rheumatoid arthritis, sickness and systemic lupus erythematosus (Kishore et al. 2011). Amongst the targeted polyphenolic compounds distinguished using RP-HPLC from the 70\% ethanol extract of underutilized plants, protocatechuic acid, vanillic acid , ferulic acid , sinapic acid , ellagic acid , myricetin and quercetin are known to possess anti-inflammatory activity (Kakkar and Bais 2014; Kim et al. 2010; Mussatto et al. 2007; Seeram et al. 2005; Ong and Khoo 1997; Seal 2016). Both M. micrantha and A. mutica contains the above compounds in substantial amount which legitimizes its activity. K. nemoralis and $C$. rutidosperma also possess these polyphenolic compounds but in lesser amount. Significant anti-inflammatoryactivity of $M$. micrantha was observed from ethyl acetate fraction in ear-inflammation on topical application of TPA. This study provides a preliminary idea about the efficacy of $70 \%$ ethanol extract on the anti-arthritic activity of the plant and also supports its traditional use in treatment of rheumatism. Our result is in congruence with prior study by Chakraborty and Roy (Chakraborty and Roy 2010), where the ethanolic extract of $C$. rutidosperma showed prominent antiarthritic activity in cottonpellet granuloma model. However $A$. mutica and $K$. nemoralis did not have any earlier report of anti-inflammatory activity. Studies on the capability of the $70 \%$ ethanol extract to hinder heat initiated protein denaturation demonstrate that these plants can be used for improvement of antiinflammatory drug.

\section{Conclusion}

The results of our current investigation support the potential role of four lesser known plants, traditionally used in India in folk medicineas an antioxidant, antidiabetic and anti-inflammatory agent. Both biochemical and biological tests were executed to provide a complete framework for each plant under investigation. All the tested plants demonstrated an amazing presence of secondary metabolites, involved in several biological activities. In particular, M.micrantha and $C$. rutidosperma has a high content of polyphenols and responsible for the significant antioxidant activity. Due to the abundance of bioactive metabolites, all these extracts were shown to be efficient, to inhibit a-amylase and a-glucosidase enzyme and also played an important role in the prevention of precipitation of the denatured protein aggregates involved in inflammation. In conclusion, all the data confirm thatthe investigated plants may be the potential sources of anti-diabetic and anti- inflammatory agent. Thus, the study has revealed that traditionally used easily available plants can be a low-cost source of important bioactive molecules with potential for herbal drug development.The specific compounds responsible for biological activities need to be explored and further investigations for the most active compounds will be done in the near future.

\section{Abbreviations}


Apluda mutica: A. mutica; Mikania micrantha: M. micrantha;Kyllinga nemoralis: K. nemoralis; Cleome rutidosperma : C. rutidosperma; DPPH:DPPH (1,1diphenyl-2-picrylhydrazyl; ABTS:2,2'-azino-bis(3-ethylbenzothiazoline-6-sulfonic acid) HPLC: High-performance liquid chromatography; PDA:Photo diode array; GAE: Gallic acid equivalent; RE : Rutin equivalent AAE: Ascorbic acid equivalent; DE: Dry extract; IC: Inhibitory concentration ; TE : Trolox equivalent ; FRAP : Ferric reducing antioxidant power ; $\mathrm{mM}$ : milimole; TPTZ : 2, 4, 6-tripyridyl triazine; $\boldsymbol{a}$ : alpha ; $\beta$ : beta; DNS : Dinitrosalicylic acid; $\mathbf{p N P G}$ : $p$ nitrophenylglucopyranoside ; SPSS : statistical package for the social sciences

\section{Declarations}

\section{Authors' contributions}

All authors were involved in the experiment, analysis, interpretation and drafting of the manuscript. All authors read and approved the final manuscript.

\section{Acknowledgement}

The authors are grateful to Dr. A. A. Mao, Director, Botanical Survey of India for providing all the facilities to carry out the research work.

\section{Competing interests}

The authors declare that they have no competing interests.

\section{Availability of data and materials}

All data that are relevant to the study are reported within the article.

\section{Consent for publication}

The authors approved the consent for publishing

\section{Ethics approval and consent to participate}

All the authors have read and agreed the ethics for publishing the manuscript.

\section{Funding}

No funding was received for this article.

\section{References}

1. Adhikari BS, Babu MM, Saklani PL, Rawat GS (2010). Medicinal plants diversity and their conservation status in Wildlife Institute of India campus, Dehra Dun. Ethnobot Leaflets14: 46-83.

2. Alam MA, Subhan N, Rahman MM, Uddin SJ, Reza HM, Sarker SD (2014) Effect of Citrus Flavonoids, Naringin and Naringenin, on metabolic syndrome and their mechanisms of action. Adv Nutr 5 : 404-417.

3. Alothman M, Bhat R, Karim AA (2009) Antioxidant capacity and phenolic content of selected tropical fruits from Malaysia, extracted with different solvents. Food Chem. 115 : 785-788.

4. Bhandari MR, Anurakkun NJ, Hong G, Kawabata J (2008) a-Glucosidase and a- amylase inhibitory activities of Nepalese medicinal herb Pakhanbhed (Bergeniaciliata, Haw.).Food Chem $106: 247-252$.

5. Calderon-Montano JM, Burgos-Moron E, Perez-Guerrero C, Lopez-Lazaro MA (2011) Review on the dietary flavonoid kaempferol. Mini Rev Med Chem 11 : 298-344.

6. Chakraborty AK, Roy HK (2010) Evaluation of anti-arthritic activity of ethanolic extract of Cleome rutidosperma. J Pharm Sci Technol 2 : $330-332$.

7. Chang JY (2009) Conformational isomers of denatured and unfolded proteins: methods of production and applications. Protein J 28 : $44-56$.

8. Chauhan AS (2001) Ethanobotanical studies in Sikkim Himalaya.Proceedings of national seminar on traditional knowledge based on herbal medicines and plant resources of north-east India.National Institute of Science Communication and Information Resources, CISR, New Delhi, 2001.

9. Chen R, Qi QL, Wang MT, Li QY (2016) Therapeutic potential of naringin: an overview. Pharm Biol 54 : 3203-3210.

10. Chetia J, Upadhyaya S, Bora DK (2014) Screening of phytochemicals, antioxidant and antimicrobial activity of some tea garden weeds of Tinsukia, Assam. Int J Pharm Sci Rev Res 26 : 193-196.

11. Datta S, Seal T, Sinha BK, Bhattacharjee S (2018a) RP-HPLC based evidences of rich sources of Phenolics and water soluble vitamins in an annual sedge Cyperus compressus. J Phytophar $7: 305-311$

12. Datta S, Sinha BK, Bhattacharjee S, Seal T (2018b) Effect of solvent extraction system on the antioxidant activities of three invasive alien species and quantification of phenolic compounds by HPLC. J Pharmacogn Phytochem 7: 3963-3970.

13. Datta S, Sinha BK, Bhattacharjee S, Seal T (2019) Nutritional composition, mineral content, antioxidant activity and quantitative estimation of water soluble vitamins and phenolics by RP-HPLC in some lesser used wild edible plants, Heliyon 5: e01431.

14. Fejes S, Blazovics A, Lugasi A, Lemberkovics E, Petri G, Kery A (2000) In vitro antioxidant activity of Anthriscus cerefolium L. (Hoffm.) extracts, J Ethnopharmacol 69 : 259-265. 
15. Florence OJ, Adeolu AA, Anthony JA (2011) Comparison of the nutritive value, antioxidant and antibacterial activities of Sonchus asper and Sonchus oleraceus. Rec Nat Prod 5 : 29-42.

16. Gordon MH (1990) The mechanism of antioxidant action in vitro. In Food Antioxidants; Hudson, B. J. F. Ed; Elsevier Applied Science; London, New York, pp 1-18.

17. Gua Q, Zhao B, Li M, Shen S, Xin W (1996) Studies on protective mechanisms of four components of green tea polyphenols against lipid peroxidation in synaptosomes. Biochim Biophys Acta 1304 : 210-222.

18. Gursoy N, Sarikurkcu C, Cengiz M, Solak MH (2009) Antioxidant activities, metal contents, total phenolics and flavonoids of seven Morchella species. Food Chem Toxicol $47: 2381-2388$.

19. Gutensperger B, Hammerli-Mier DE, Escher FE (1998) Rosemary extract and precooking effects on lipid oxidation in heat sterilized meat. J Food Sci 63 : 955-957.

20. Hagerman AE, Riedl KM, Jones GA, Sovik KN, Ritchard NT, Hartzfeld PW, Riechel TL (1998) High molecular weight plant polyphenolics (Tannins) as biological antioxidants. J Agri Food Chem $46: 1887-1892$.

21. Halliwell B, Murcia HA, Chirco S, Aruoma OI (1995) Free radicals and antioxidants in food and in vivo: what they do and how they work. CRC Cr. Rev. Food Sci. $35: 7-20$.

22. Jayaprakasha GK, Girennavar B, Patil BS (2008) Radical scavenging activities of Rio red grapefruits and sour orange fruit extracts in different in vitro model systems. Bioresour Technol 99 : 4484-4494.

23. Kakkar S, Bais S (2014) A review on protocatechuic acid and its pharmacological potential. ISRN Pharmacol. 26 : 1-9.

24. Kanno S, Tomizawa A, Hiura T, Osanai Y, Shouji A, Ujibe M, Ohtake T, Kimura K, Ishikawa M (2005) Inhibitory effects of naringenin on tumor growth in human cancer cell lines and sarcoma S-180-implanted miceBiol. Pharm. Bull. $28: 527-530$.

25. Khadem S, Marles RJ (2010) Monocyclic phenolic acids; hydroxy- and polyhydroxybenzoic acids: occurrence and recent bioactivity studies. Molecules 15 :7985-8005.

26. Khory NR, Katrak NN (1999) Materia medica of India and their therapeutics; BDH Printers: New Delhi, p. 380.

27. Kim SJ, Kim MC, Um JY, Hong SH (2010) The beneficial effect of vanillic acid on Ulcerative Colitis, Molecules 15 : $7208-7217$.

28. Kim YM, Jeong YK, Wang MH, Lee YW, Rhee HI (2005) Inhibitory effect of pine extract on a-glucosidase activity and postprandial hyperglycemia, Nutr. 21: 756-761.

29. Kishore G, Siva G, Sindhu Priya ES (2011) In vitro anti-Inflammatory and anti-arthritic activity of leaves of Physalis angulata L. Int J Pharm Ind Res 1 : 211-213.

30. Lin JP, Yang JS, Lin JJ, Lai KC, Lu HF, Ma CY, Wu RS, Wu KC, Chueh FS, Wood WG, Chung JG (2012) Rutin inhibits human leukemia tumor growth in a murine xenograft model in vivo. Environ. Toxicol. $27: 480-484$.

31. Lopez A, Rico M, Rivero A, de Tangil MS (2011) The effects of solvents on the phenolic contents and antioxidant activity of Stypocaulon scoparium algae extracts. Food Chem $125: 1104-1109$.

32. Mathew S, Abraham TE (2006) In vitro antioxidant activity and scavenging effects of Cinnamomum verum leaf extracts assayed by different methodologies, Food Chem Toxicol 44 : 198-206.

33. McCue PP, Shetty K (2004) Inhibitory effects of rosmarinic acid extracts on porcine pancreatic amylase in vitro. Asia Pac J Clin Nutr 13: $101-106$.

34. Mohammad A, Elham KK (2013) Medicinal uses and chemistry of flavonoid contents of some common edible tropical plants. J Paramed Sci 4 : $119-38$.

35. Moradi-Afrapoli F, Asghari B, Saeidnia S, Ajani Y, Mirjani M, Malmir M, Bazaz RD, Hadjiakhoondi A, Salehi P, Hamburger M, Yassa N (2012) In vitro aglucosidase inhibitory activity of phenolic constituents from aerial parts of Polygonum hyrcanicum DARU J Pharm Sci $20: 37$.

36. Mukhopadhyay S, Luthria DL, Robbins RJ (2006) Optimization of extraction process for phenolic acids from black cohosh (Cimicifuga racemosa) by pressurized liquid extraction. J Sci Food Agric 86 : 156-162.

37. Mussatto G, Dragone I, Roberto C (2007) Ferulic and p-coumaric acids extraction by alkaline hydrolysis of brewer's spent grain. Ind Crops Prod. 25 : 231237.

38. Nickavar B, Abolhasani L, Izadpanah, H (2008) a- Amylase inhibitory activities of six Salvia species. Iran J Pharm Res $7: 297-303$.

39. Nurdiana S, NurAjeerah S, NurFarhana AS, SitiKhairiyah MH, Norashirene M (2013) Hypoglycaemic, antioxidant and wound healing activities of Mikania micrantha leaves extract in normal and alloxan-induced diabetic rats. J Sci Lett 7: 6-10.

40. Okoro IO, Umar IA, Atawodi SE, Anigo KM (2014) Comparative antihyperglycemic effect of petroleum ether, acetone, ethanol and aqueous extracts of Cleome rutidosperma DC and Senecio biafrae (Oliv. and Hiern) in Streptozotocin-induced diabetic mice.Br. J. Pharmacol. Toxicol. 5 : 115-124.

41. Ong KC, Khoo HE (1997) Biological effects of myricetin. Gen Pharmacol 29 : 121-126.

42. Parekh J, Chanda S (2007) Antibacterial and phytochemical studies on twelve species of Indian medicinal plants. Afr J Biomed Res 10: $175-181$.

43. Pourmorad F, Hosseinimehr SJ, Shahabimajd N (2006) Antioxidant activity, phenol and flavonoid contents of some selected Iranian medicinal plants. Afr J Biotechnol 5 : 1142-1145.

44. Quanico JP, Amor EC, Perez GG (2008) Analgesic and hypoglycemic activities of Bixa orellana, Kyllinga monocephala and Luffa acutangula Philipp. J Sci $137: 69-76$.

45. Ramadoss KSI, Devadasu C, Srinivasa Babu P (2015) Isolation, characterization and RP-HPLC estimation of p-coumaric acid from methanolic extract of Durva Grass (Cynodondactylon L.) (Pers.). Int J Anal Chem 1-7.

46. Reddy ARK, Grace JR (2016) In vitro Evaluation of Antioxidant Activity of Brugeiera gymnorrhiza and Aegialitis rotundifolia Med Aromat Plants 5 : 231. 
47. Saeed N, Khan MR, Shabbir M (2012) Antioxidant activity, total phenolic and total flavonoid contents of whole plant extracts Torilis leptophylla L. BMC Complem Altern M $12: 221-232$.

48. Sala A, Recio MD, Giner RM, Manez S, Tournier H, Schinella G (2002) Anti-inflammatory and antioxidant properties of Helichrysum italicum. J Pharm Pharmacol 54 : 365-71.

49. Seal T (2016) HPLC determination of phenolic acids, flavonoids and ascorbic acid in four different solvent extracts of Zanthoxylum acanthopodium, a wild edible plant of Meghalaya. Int J Pharm Pharm Sci 8 : 103-109.

50. Seal K, Chaudhuri K, Pillai B (2017) Nutraceutical and antioxidant properties of Cucumis hardwickii Royle: A potent wild edible fruit collected from Uttarakhand, India. J Pharmacog Phytochem 6 : 1837-1847.

51. Seal T (2014) Antioxidant activities of some wild vegetables of North-Eastern Region in India and effect of solvent extraction system. Int J Pharm Pharm Sci $6: 315-319$.

52. Seal T, Chaudhuri K (2015) Quantitative HPLC analysis of phenolic acids, flavonoids and ascorbic acid in four different solvent extracts of Bauhinia purpurea and Clerodendroncolebrookianum, wild edible plants of North-Eastern region in India. J Chem Pharm Res 7: 427-437

53. Seal T, Pillai B, Chaudhuri K (2016) Identification and quantification of phenolic acids by HPLC, in three wild edible plants viz. Viburnum foetidum, Houttuynia cordata and Perilla ocimoides collected from North-Eastern Region in India. Int J Curr Pharm Rev Res 7: $267-274$.

54. Seal T, Pillai B, Chaudhuri K (2013) Effect of solvent extraction system on the antioxidant activity of some selected wild leafy vegetables of Meghalaya state in India, Int J Pharm Sci Res 4: 1046-1051.

55. Seeram NP, Adams LS, Henning SM, Niu YT, Zhang YJ, Nair MG, Heber D (2005) In vitro antiproliferative, apoptotic and antioxidant activities of punica lagin, ellagic acid and a total pomegranate tannin extract are enhanced in combination with other polyphenols as found in pomegranate juice. $\mathrm{J}$ Nutr Biochem $16: 360-367$.

56. Shai LJ, Masoko P, Mokgptho MP, Magano SR, Mogale AM, Boaduo N, Ellof JNS (2010)Yeast alpha-glucosidase inhibitory and antioxidant activities of six medicinal plants collected in Phalaborwa, South Africa. Afr J Bot 76 : 465-470.

57. Shil S, Dutta Choudhury M (2009) Indigenous Knowledge on Healthcare Practices by the Reang Tribe of Dhalai District of Tripura, North East India. Ethnobot Leaflets 13: 775-790.

58. Shukla AN, Srivastava S, Rawat AKS (2013) A survey of traditional medicinal plants of Uttar Pradesh (India) -used in treatment of infectious diseases. Nat Sci 11: 24-36.

59. Silja VP, Samitha VK, Mohanan KV (2008) Ethnomedicinal plant knowledge of the Mullu Kuruma tribe of wayanad district, Kerala. Indian J Tradit Knowl 7 :604-612.

60. Singh HP, Kaur S, Negi K, Kumari S, Saini V, Batish DR (2012) Assessment of in vitro antioxidant activity of essential oil of Eucalyptus citriodora (lemonscented Eucalypt; Myrtaceae) and its major constituents. LWT Food Sci Technol 48 : 237-241.

61. Spingo G, Tramelli L, de Faveri DM (2007) Effects of extraction time, temperature and solvent on concentration and antioxidant activity of grape marc phenolics. J Food Eng 81 : 200-208.

62. Srinivasan K, Kaul CL, Ramarao P (2005) Partial protective effect of rutin on multiple low dose streptozotocin-induced diabetes in mice. Indian J Pharmacol 37 : 327-328.

63. Sultana B, Anwar F, Ashraf M (2009) Effect of extraction solvent/technique on the antioxidant activity of selected medicinal plant extracts. Molecules 14: 2167- 2180.

64. Tadera K, Minami Y, Takamatsu K, Matsuoka K (2006) Inhibition of a-glucosidase and a- amylase by flavonoids. J Nutr Sci Vitaminol 52 : $149-153$.

65. Uma DB, Ho CW, Wan WM, Aida WM (2010) Optimization of extraction parameters of total phenolic compounds from Henna (Lawsoniainermis) leaves. Sains Malays. 39 : 119-128.

66. Vallabh D, Varsha MJ, Kadam VJ (2009) In vitro anti-arthritic activity of Abutilon indicum (Linn.) Sweet. J Pharm Res 49 : $644-645$.

67. Vasu K, Goud JV, Suryam A, Singara CMA (2009) Biomolecular and phytochemical analyses of three aquatic angiosperms. Afr J Microbiol Res 3: 418421.

68. Vattem DA, Shetty K (2005) Biological function of ellagic acid: A review. J Food Biochem 29 : 234-266.

69. Velioglu YS, Mazza G, Oomah BD (1998) Antioxidant activity and total phenolics in selected fruits, vegetables and grain products. J Agric Food Chem 46 : 4113-4117.

70. Warrier PK, Nambiar VPK, Ramankutty C (1995) Indian Medicinal Plants: A Compendium of 500 Species, vol. 3. Orient Longman Ltd., Madras.

71. Yamaguchi T, Takamura H, Matoba T, Terao J (1998) HPLC method for evolution of the free radical-scavenging activity of foods by using 1,1dicrylhydrazyl. Bioscience Biotechnology and Biochemistry 62 : 1201-1204.

72. Yang Z, Kuboyama T, Tohda C (2017) A systematic strategy for discovering a therapeutic drug for Alzheimer's Disease and its target molecule. Front Pharmacol. 8.

73. Zengin G, Cakmak YS, Guler GO, Aktumsek A (2011) Antioxidant properties of methanolic extract and fatty acid composition of Centaurea urvillei DC. subsp. hayekiana Wagenitz. Rec Nat Prod 5:123-132.

74. Zou Y, Lu Y, Wei D (2004) Antioxidant activity of a flavonoid-rich extract of Hypericum perforatum L. in vitro. J Agric Food Chem 52 : $5032-5039$.

\section{Tables}


Table 1

Extractive value, total phenolic and total flavonoid content of the investigated plants in four different solvent system

\begin{tabular}{|c|c|c|c|c|c|c|c|c|c|c|c|}
\hline \multirow[t]{2}{*}{ Plant } & \multicolumn{4}{|c|}{ Extractive value (\%) } & \multicolumn{4}{|c|}{$\begin{array}{l}\text { TPCmg gallic acid equivalent (GAE)/g dry } \\
\text { extract }\end{array}$} & \multicolumn{3}{|c|}{ TFCmg rutin equivalent (RE) / g dry ex } \\
\hline & $\begin{array}{l}70 \% \\
\text { Aq. } \\
\text { ethanol }\end{array}$ & Methanol & Chloroform & Benzene & $\begin{array}{l}70 \% \\
\text { Aq. } \\
\text { ethanol }\end{array}$ & Methanol & Chloroform & Benzene & $\begin{array}{l}70 \% \\
\text { Aq. } \\
\text { ethanol }\end{array}$ & Methanol & Chloroform \\
\hline A. mutica & $\begin{array}{l}6.58 \pm \\
0.08^{b}\end{array}$ & $\begin{array}{l}3.92 \pm \\
0.05^{c}\end{array}$ & $\begin{array}{l}4.95 \pm \\
0.09^{a}\end{array}$ & $\begin{array}{l}3.34 \pm \\
0.12^{\mathrm{a}}\end{array}$ & $\begin{array}{l}141.94 \\
\pm 0.67^{d}\end{array}$ & $\begin{array}{l}66.54 \pm \\
2.78^{d}\end{array}$ & $\begin{array}{l}20.33 \pm \\
0.34{ }^{d}\end{array}$ & $\begin{array}{l}15.68 \pm \\
1.32^{\mathrm{d}}\end{array}$ & $\begin{array}{l}23.27 \\
\pm 0.04^{c}\end{array}$ & $\begin{array}{l}18.92 \pm \\
0.14^{d}\end{array}$ & $\begin{array}{l}6.54 \pm \\
0.17^{d}\end{array}$ \\
\hline M. micrantha & $\begin{array}{l}7.21 \pm \\
0.07^{a}\end{array}$ & $\begin{array}{l}5.54 \pm \\
0.19^{b}\end{array}$ & $\begin{array}{l}1.79 \pm \\
0.12^{b}\end{array}$ & $\begin{array}{l}0.64 \pm \\
0.12^{c}\end{array}$ & $\begin{array}{l}230.45 \\
\pm 0.12^{\mathrm{a}}\end{array}$ & $\begin{array}{l}162.95 \pm \\
0.44^{\mathrm{a}}\end{array}$ & $\begin{array}{l}129.35 \pm \\
0.72^{\mathrm{a}}\end{array}$ & $\begin{array}{l}104.14 \\
\pm 1.71^{\mathrm{a}}\end{array}$ & $\begin{array}{l}41.79 \\
\pm 0.07^{b}\end{array}$ & $\begin{array}{l}38.76 \pm \\
0.06^{b}\end{array}$ & $\begin{array}{l}29.84 \pm \\
0.22^{b}\end{array}$ \\
\hline K. nemoralis & $\begin{array}{l}3.39 \pm \\
0.02^{c}\end{array}$ & $\begin{array}{l}1.49 \pm \\
0.19^{d}\end{array}$ & $\begin{array}{l}0.59 \pm \\
0.34^{d}\end{array}$ & $\begin{array}{l}1.01 \pm \\
0.06^{\mathrm{b}}\end{array}$ & $\begin{array}{l}172.79 \\
\pm 0.33^{c}\end{array}$ & $\begin{array}{l}122.56 \pm \\
1.28^{c}\end{array}$ & $\begin{array}{l}80.86 \pm \\
0.85^{c}\end{array}$ & $\begin{array}{l}68.72 \pm \\
1.28^{\mathrm{C}}\end{array}$ & $\begin{array}{l}23.62 \\
\pm 0.13^{c}\end{array}$ & $\begin{array}{l}20.66 \pm \\
0.55^{c, d}\end{array}$ & $\begin{array}{l}11.76 \pm \\
0.28^{c}\end{array}$ \\
\hline $\begin{array}{l}\text { C. } \\
\text { rutidosprema }\end{array}$ & $\begin{array}{l}2.35 \pm \\
0.08^{d}\end{array}$ & $\begin{array}{l}7.17 \pm \\
0.16^{\mathrm{a}}\end{array}$ & $\begin{array}{l}1.15 \pm \\
0.09^{c}\end{array}$ & $\begin{array}{l}0.54 \pm \\
0.12^{d}\end{array}$ & $\begin{array}{l}200.90 \\
\pm 0.19^{b}\end{array}$ & $\begin{array}{l}127.58 \pm \\
0.45^{b}\end{array}$ & $\begin{array}{l}91.75 \pm \\
2.64^{b}\end{array}$ & $\begin{array}{l}75.29 \pm \\
3.08^{\mathrm{b}}\end{array}$ & $\begin{array}{l}71.05 \\
\pm 0.06^{\mathrm{a}}\end{array}$ & $\begin{array}{l}69.05 \pm \\
0.06^{\mathrm{a}}\end{array}$ & $\begin{array}{l}57.78 \pm \\
0.35^{\mathrm{a}}\end{array}$ \\
\hline
\end{tabular}

(Values are mean of three independent replicates \pm SEM. Means that do not share a letter within the same column are significantly different at $p \leq 0.05$ )

Table 2

Radical scavenging activity (using DPPH \&ABTS ) and FRAP of the investigated plants in four different solvent system

\begin{tabular}{|c|c|c|c|c|c|c|c|c|c|c|c|}
\hline \multirow[t]{2}{*}{ Plant } & \multicolumn{4}{|c|}{ DPPH (\% of inhibition) } & \multicolumn{4}{|c|}{ ABTS (\% of inhibition) } & \multicolumn{3}{|c|}{ FRAP( $\mu \mathrm{M}$ Trolox equivalent/ g dry extr } \\
\hline & $\begin{array}{l}70 \% \\
\text { Aq. } \\
\text { ethanol }\end{array}$ & Methanol & Chloroform & Benzene & $\begin{array}{l}70 \% \\
\text { Aq. } \\
\text { ethanol }\end{array}$ & Methanol & Chloroform & Benzene & $\begin{array}{l}70 \% \\
\text { Aq. } \\
\text { ethanol }\end{array}$ & Methanol & Chloroform \\
\hline A. mutica & $\begin{array}{l}53.35 \\
\pm 0.13^{d}\end{array}$ & $\begin{array}{l}13.61 \pm \\
0.49^{d}\end{array}$ & $\begin{array}{l}9.32 \pm \\
0.18^{d}\end{array}$ & $\begin{array}{l}5.51 \pm \\
0.12^{\mathrm{a}}\end{array}$ & $\begin{array}{l}72.77 \\
\pm 0.24^{b}\end{array}$ & $\begin{array}{l}51.96 \pm \\
0.23^{d}\end{array}$ & $\begin{array}{l}32.63 \pm \\
0.61^{c}\end{array}$ & $\begin{array}{l}5.34 \pm \\
0.99^{c}\end{array}$ & $\begin{array}{l}2.15 \pm \\
0.002^{d}\end{array}$ & $\begin{array}{l}2.02 \pm \\
0.004^{d}\end{array}$ & $\begin{array}{l}1.34 \pm \\
0.003^{d}\end{array}$ \\
\hline M. micrantha & $\begin{array}{l}87.01 \\
\pm 0.22^{a}\end{array}$ & $\begin{array}{l}56.62 \pm \\
0.29^{b}\end{array}$ & $\begin{array}{l}30.33 \pm \\
0.13^{a}\end{array}$ & $\begin{array}{l}3.57 \pm \\
0.14^{b}\end{array}$ & $\begin{array}{l}93.30 \\
\pm 0.84^{a}\end{array}$ & $\begin{array}{l}77.71 \pm \\
0.36^{b}\end{array}$ & $\begin{array}{l}51.910 \pm \\
0.23^{b}\end{array}$ & $\begin{array}{l}8.48 \pm \\
0.27^{b}\end{array}$ & $\begin{array}{l}4.12 \pm \\
0.004^{a}\end{array}$ & $\begin{array}{l}3.71 \pm \\
0.002^{a}\end{array}$ & $\begin{array}{l}3.06 \pm \\
0.002^{a}\end{array}$ \\
\hline K. nemoralis & $\begin{array}{l}61.57 \\
\pm 0.11^{\mathrm{c}}\end{array}$ & $\begin{array}{l}49.04 \pm \\
0.29^{c}\end{array}$ & $\begin{array}{l}29.17 \pm \\
0.17^{a}, b\end{array}$ & $\begin{array}{l}3.31 \pm \\
0.22^{b}\end{array}$ & $\begin{array}{l}72.43 \\
\pm 0.33^{b}\end{array}$ & $\begin{array}{l}76.39 \pm \\
0.05^{b, c}\end{array}$ & $\begin{array}{l}52.55 \pm \\
0.07^{a, b}\end{array}$ & $\begin{array}{l}5.62 \pm \\
0.09^{c}\end{array}$ & $\begin{array}{l}3.31 \pm \\
0.002^{b, c}\end{array}$ & $\begin{array}{l}2.66 \pm \\
0.004^{c}\end{array}$ & $\begin{array}{l}2.03 \pm \\
0.004^{c}\end{array}$ \\
\hline $\begin{array}{l}\text { C. } \\
\text { rutidosprema }\end{array}$ & $\begin{array}{l}83.85 \\
\pm 0.08^{b}\end{array}$ & $\begin{array}{l}60.71 \pm \\
0.17^{a}\end{array}$ & $\begin{array}{l}13.33 \pm \\
0.17^{c}\end{array}$ & $\begin{array}{l}1.76 \pm \\
0.09^{c}\end{array}$ & $\begin{array}{l}92.67 \\
\pm 0.13^{\mathrm{a}}\end{array}$ & $\begin{array}{l}81.06 \pm \\
0.14^{\mathrm{a}}\end{array}$ & $\begin{array}{l}53.38 \pm \\
0.18^{a}\end{array}$ & $\begin{array}{l}10.99 \pm \\
0.16^{\mathrm{a}}\end{array}$ & $\begin{array}{l}3.73 \pm \\
0.003^{b}\end{array}$ & $\begin{array}{l}3.64 \pm \\
0.003^{b}\end{array}$ & $\begin{array}{l}2.77 \pm \\
0.003^{b}\end{array}$ \\
\hline
\end{tabular}

(Values are mean of three independent replicates \pm SEM. Means that do not share a letter within the same column are significantly different at $p \leq 0.05$ )

Table 3

Reducing property, metal chelating property and anti-lipid peroxidation ability of the investigated plants in four different solvent system.

\begin{tabular}{|c|c|c|c|c|c|c|c|c|c|c|c|}
\hline \multirow[t]{2}{*}{ Plant } & \multicolumn{4}{|c|}{$\begin{array}{l}\text { Reducing property(mg Ascorbic acid equivalent } \\
\text { /g dry extract) }\end{array}$} & \multicolumn{4}{|c|}{ Metal chelating(\% of inhibition) } & \multicolumn{3}{|c|}{ Anti-lipid peroxidation(\% of inhibition) } \\
\hline & $\begin{array}{l}70 \% \\
\text { Aq. } \\
\text { ethanol }\end{array}$ & Methanol & Chloroform & Benzene & $\begin{array}{l}70 \% \\
\text { Aq. } \\
\text { ethanol }\end{array}$ & Methanol & Chloroform & Benzene & $\begin{array}{l}70 \% \\
\text { Aq. } \\
\text { ethanol }\end{array}$ & Methanol & Chloroform \\
\hline A. mutica & $\begin{array}{l}48.71 \\
\pm 0.48^{c}\end{array}$ & $\begin{array}{l}12.12 \pm \\
0.31^{d}\end{array}$ & $\begin{array}{l}5.11 \pm \\
0.14^{d}\end{array}$ & $\begin{array}{l}1.12 \pm \\
0.04^{d}\end{array}$ & $\begin{array}{l}51.55 \\
\pm 0.27^{d}\end{array}$ & $\begin{array}{l}35.93 \pm \\
0.21^{c}\end{array}$ & $\begin{array}{l}22.33 \pm \\
0.15^{d}\end{array}$ & $\begin{array}{l}9.11 \pm \\
0.44^{d}\end{array}$ & $\begin{array}{l}59.78 \\
\pm 0.37^{c}\end{array}$ & $\begin{array}{l}44.08 \pm \\
0.06^{d}\end{array}$ & $\begin{array}{l}21.78 \pm \\
0.56^{d}\end{array}$ \\
\hline M. micrantha & $\begin{array}{l}66.52 \\
\pm 0.06^{a}\end{array}$ & $\begin{array}{l}36.21 \pm \\
0.25^{\mathrm{a}}\end{array}$ & $\begin{array}{l}23.17 \pm \\
0.36^{\mathrm{a}}\end{array}$ & $\begin{array}{l}14.11 \pm \\
0.15^{\mathrm{a}}\end{array}$ & $\begin{array}{l}71.91 \\
\pm 0.29^{a}\end{array}$ & $\begin{array}{l}61.87 \pm \\
0.16^{\mathrm{a}}\end{array}$ & $\begin{array}{l}52.170 \pm \\
0.65^{a}\end{array}$ & $\begin{array}{l}33.21 \pm \\
0.65^{a}\end{array}$ & $\begin{array}{l}63.15 \\
\pm 0.01^{\mathrm{a}}\end{array}$ & $\begin{array}{l}50.07 \pm \\
0.05^{a, b}\end{array}$ & $\begin{array}{l}38.55 \pm \\
0.07^{b}\end{array}$ \\
\hline K. nemoralis & $\begin{array}{l}48.24 \\
\pm 0.18^{c}\end{array}$ & $\begin{array}{l}33.98 \pm \\
0.75^{b}\end{array}$ & $\begin{array}{l}19.06 \pm \\
0.45^{\mathrm{b}}\end{array}$ & $\begin{array}{l}11.46 \pm \\
0.35^{b}\end{array}$ & $\begin{array}{l}64.78 \\
\pm 0.22^{c}\end{array}$ & $\begin{array}{l}49.51 \pm \\
0.28^{b}\end{array}$ & $\begin{array}{l}31.41 \pm \\
0.62^{c}\end{array}$ & $\begin{array}{l}11.25 \pm \\
0.12^{c}\end{array}$ & $\begin{array}{l}58.96 \\
\pm 0.52^{c} \\
d\end{array}$ & $\begin{array}{l}46.41 \pm \\
0.12^{c}\end{array}$ & $\begin{array}{l}29.45 \pm \\
0.17^{c}\end{array}$ \\
\hline $\begin{array}{l}\text { C. } \\
\text { rutidosprema }\end{array}$ & $\begin{array}{l}51.90 \\
\pm 0.10^{\mathrm{b}}\end{array}$ & $\begin{array}{l}26.14 \pm \\
0.25^{c}\end{array}$ & $\begin{array}{l}14.22 \pm \\
0.32^{\mathrm{c}}\end{array}$ & $\begin{array}{l}8.53 \pm \\
0.12^{c}\end{array}$ & $\begin{array}{l}67.44 \\
\pm 0.22^{b}\end{array}$ & $\begin{array}{l}61.20 \pm \\
0.24^{\mathrm{a}}\end{array}$ & $\begin{array}{l}48.30 \pm 0 \\
57^{\mathrm{b}}\end{array}$ & $\begin{array}{l}21.44 \pm \\
0.28^{\mathrm{b}}\end{array}$ & $\begin{array}{l}61.42 \\
\pm 0.12^{b}\end{array}$ & $\begin{array}{l}50.22 \pm \\
0.29^{a}\end{array}$ & $\begin{array}{l}39.26 \pm \\
0.37^{a}\end{array}$ \\
\hline
\end{tabular}

(Values are mean of three independent replicates \pm SE. Means that do not share a letter within the same column are significantly different at $p \leq 0.05$ ) 
Table 4

Phenolic acids and flavonoid quantification of experimental underutilized plants by RP-HPLC method (mg/ $100 \mathrm{~g}$ plant material)

\begin{tabular}{|c|c|c|c|c|}
\hline Phenolic acids and flavonoids & $\begin{array}{l}\text { A. mutica } \\
\text { (mg/ } 100 \mathrm{~g} \text { plant material) }\end{array}$ & $\begin{array}{l}\text { M. micrantha } \\
\text { (mg/ } 100 \text { g plant material) }\end{array}$ & $\begin{array}{l}\text { K. nemoralis } \\
\text { (mg/ } 100 \mathrm{~g} \text { plant material) }\end{array}$ & $\begin{array}{l}\text { C. rutidosprema } \\
\text { (mg/ } 100 \mathrm{~g} \text { plant material) }\end{array}$ \\
\hline Gallic acid & ND & ND & ND & ND \\
\hline Protocatechuic acid & ND & $0.399 \pm 0.002^{a}$ & ND & ND \\
\hline Gentisic acid & ND & ND & ND & ND \\
\hline p-Hydroxy benzoic acid & $0.077 \pm 0.001^{c}$ & $0.092 \pm 0.001^{b}$ & $0.349 \pm 0.005^{a}$ & ND \\
\hline Catechin & ND & ND & ND & ND \\
\hline Chlorogenic acid & $0.630 \pm 0.001^{a}$ & $0.218 \pm 0.001^{b}$ & $0.056 \pm 0.003^{c}$ & ND \\
\hline Vanillic acid & $0.089 \pm 0.001^{c}$ & $0.193 \pm 0.003^{b}$ & $2.113 \pm 0.004^{a}$ & ND \\
\hline Caffeic acid & $0.629 \pm 0.001^{a}$ & ND & ND & ND \\
\hline Syringic acid & $2.869 \pm 0.002^{\mathrm{a}}$ & $0.115 \pm 0.002^{c}$ & ND & $1.609 \pm 0.003^{b}$ \\
\hline p-Coumaric acid & $1.287 \pm 0.002^{a}$ & $0.336 \pm 0.003^{b}$ & ND & $0.232 \pm 0.002^{b, c}$ \\
\hline Ferulic acid & $1.382 \pm 0.001^{a}$ & $0.104 \pm 0.002^{d}$ & $0.608 \pm 0.004^{b}$ & $0.393 \pm 0.002^{c}$ \\
\hline Sinapic acid & $1.809 \pm 0.001^{\mathrm{a}}$ & $0.725 \pm 0.001^{b}$ & $0.172 \pm 0.006^{c}$ & $0.039 \pm 0.002^{d}$ \\
\hline Salicylic acid & ND & $1.559 \pm 0.004^{a}$ & ND & ND \\
\hline Naringin & ND & $5.407 \pm 0.003^{\mathrm{a}}$ & ND & ND \\
\hline Rutin & $0.677 \pm 0.001^{b}$ & $1.096 \pm 0.002^{a}$ & ND & $0.050 \pm 0 . .001^{c}$ \\
\hline Ellagic acid & $0.801 \pm 0.001^{b}$ & $0.638 \pm 0.002^{c}$ & ND & $4.372 \pm 0.002^{a}$ \\
\hline Myricetin & $2.366 \pm 0.001^{a}$ & ND & $0.169 \pm 0.002^{c}$ & $0.292 \pm 0.001^{b}$ \\
\hline Quercetin & $0.211 \pm 0.002^{b, c}$ & $0.504 \pm 0.002^{a}$ & $0.119 \pm 0.003^{d}$ & $0.296 \pm 0.003^{b}$ \\
\hline Naringenin & ND & ND & ND & $0.114 \pm 0.002^{a}$ \\
\hline Apigenin & ND & $0.333 \pm 0.001^{b}$ & $0.165 \pm 0.003^{c}$ & $1.509 \pm 0.004^{a}$ \\
\hline Kaempferol & ND & $0.093 \pm 0.001^{b}$ & $0.162 \pm 0.003^{a}$ & $0.083 \pm 0.001^{b}$ \\
\hline
\end{tabular}

Table 5

a-amylase, a-glucosidase and inhibition of protein denaturation study of $70 \%$ aq. ethanol extracts of the plants

\begin{tabular}{|llll|}
\hline Plant extract/Standard & $\begin{array}{l}\text { a- amylase } \\
\mathrm{IC}_{50}(\mu \mathrm{g} / \mathrm{cc})\end{array}$ & $\begin{array}{l}\text { a- glucosidase } \\
\mathrm{IC}_{50}(\mu \mathrm{g} / \mathrm{cc})\end{array}$ & $\begin{array}{l}\text { protein denaturation } \\
\mathrm{IC}_{50}(\mu \mathrm{g} / \mathrm{cc})\end{array}$ \\
\hline Acarbose (Standard) & $53.8 \pm 0.009^{\mathrm{e}}$ & $79.48 \pm 0.006^{\mathrm{e}}$ & - \\
\hline Diclofenac (Standard) & - & - & $31.32 \pm 0.004^{\mathrm{e}}$ \\
\hline A.mutica & $63.01 \pm 0.004^{\mathrm{C}}$ & $168.84 \pm 0.014^{\mathrm{c}}$ & $166.03 \pm 0.013^{\mathrm{b}}$ \\
\hline M.micrantha & $58.44 \pm 0.012^{\mathrm{d}}$ & $113.31 \pm 0.010^{\mathrm{d}}$ & $89.27 \pm 0.008^{\mathrm{d}}$ \\
\hline K. nemoralis & $72.62 \pm 0.007^{\mathrm{b}}$ & $236.9 \pm 0.003^{\mathrm{a}}$ & $98.78 \pm 0.007^{\mathrm{c}}$ \\
\hline C. rutidosperma & $77.52 \pm 0.011^{\mathrm{a}}$ & $216.37 \pm 0.008^{\mathrm{b}}$ & $201.58 \pm 0.011^{\mathrm{a}}$ \\
\hline
\end{tabular}

\section{Supplementary Files}

This is a list of supplementary files associated with this preprint. Click to download. 
- Graphicalabstract.docx

Page 14/14 